\title{
The effect of human umbilical cord-derived mesenchymal stem cell conditioned medium on the peripheral nerve regeneration of injured rats
}

\author{
Ria Margiana1, Renindra Ananda Aman², Jeanne Adiwinata Pawitan ${ }^{3,4,5^{*}}$, Ahmad Aulia Jusuf ${ }^{3,5}$, Nurhadi Ibrahim ${ }^{6}$, \\ Heri Wibowo ${ }^{7}$
}

\begin{abstract}
Peripheral nerve injury occurs in 3-10\% of extremity trauma patients. Mesenchymal stem cells (MSCs) have been used in injuries. Nevertheless, the mechanism of human umbilical cord MSCs (UC-MSCs) and/or their conditioned medium (CM) capacity in regenerating peripheral nerves is not widely known. This study is aimed to determine the mechanism, of UC-MSC CM in improving the structure and function of the nerves after peripheral nerve injury. This experimental study used Sprague-Dawley rats. The experimental animals were divided into 3 groups: control (Sham [SH]), and treatment groups (standard therapy [ST] and CM). The sciatic nerve of the SH group was not injured (only exposed and closed), while those of the ST and CM groups were both cut and given standard sutures. The CM group was treated with topical UC-MSCs CM. The study was divided into two stages i.e. a short-term and long-term research to check the parameters at 7 and 70 days post injury (dPI), respectively. The parameters collected were motor functions (walking analysis), electrophysiology and structural parameters. There were signs of nerve injury in all rats on $3 \mathrm{dPI}$. CM group showed faster recovery on $14 \mathrm{dPI}$ compared with the ST group that only showed improvement after the 28th dPI. Electrophysiological images showed better electrical conduction in CM than ST group, while histological features showed higher S100 marker was expressed in CM compared with ST, as well as SH group on 7 and $70 \mathrm{dPI}$. Overall, UC-MSC CM affected peripheral nerve regeneration after $14 \mathrm{dPI}$.
\end{abstract}

Keywords: conditioned medium, umbilical cord, growth factor, sprague-dawley rats

\section{INTRODUCTION}

Acute peripheral nerve injury occurs in 3-10\% of extremity trauma patients (33). The injury is thought to have occurred in 18 out of 100,000 people each year in developed countries, and the number is relatively higher in developing countries (24). It is important to learn about peripheral nerve injury because it can cause disability in young male adults, who generally are of working age. The target of healing a nerve injury is to return of nerve function as it was before the injury. To achieve the therapeutic target of nerve injury, a huge cost $(33,47)$, long duration of hospitalization and outpatient treatment are required, and the result is influenced by various factors (47).

The repair of nerve injury continues to be a major challenge in the management of peripheral nerve injury therapy. The repair of nerve injury to normal sensory and motor functions is very rarely achieved even though nerve and nerve tissue repairs have occurred $(12,29,25,22,28)$. One factor that influences the management of peripheral nerve injury is the microenvironment factor (niche). It is suspected that the microenvironment of tissues can be enhanced by administering supportive therapy such as the administration of Mesenchymal Stem Cells (MSC) and/or MSC conditioned

\footnotetext{
1 Department of Anatomy, Faculty of Medicine, Universitas Indonesia, Indonesia.

2 Department of Neurosurgery, Faculty of Medicine, Universitas Indonesia, Dr. Cipto Mangunkusumo General Hospital/Faculty of Medicine Universitas Indonesia, Indonesia.

3 Departemen Histology, Faculty of Medicine, Universitas Indonesia, Indonesia.

4 Stem Cell Medical Technology Integrated Service Unit, Dr. Cipto Mangunkusumo General Hospital/Faculty of Medicine Universitas Indonesia, Indonesia.

5 Stem Cell and Tissue Engineering Research Center, Indonesia Medical Education and Research Institute (IMERI), Faculty of Medicine Universitas Indonesia, Indonesia

6 Department of Physiology, Faculty of Medicine, Universitas Indonesia, Indonesia.

7 Department of Parasitology, Faculty of Medicine, Universitas Indonesia, Indonesia.
}

\section{Correspondence: Jeanne Adiwinata Pawitan}

Universitas Indonesia, Jakarta, Indonesia.

E-mail: jeanneadiwip@gmail.com

Received: 22 Aug 2019, Accepted: 18 Nov 2019

(C) 2019 by the authors; licensee Modestum Ltd., UK. This article is an open access article distributed under the terms and conditions of the Creative Commons Attribution License (http://creativecommons.org/licenses/by/4.0/). 
medium containing many important growth factors for the regeneration of peripheral nerve injury. Various growth factors secreted by MSC are thought to have a positive effect on the regeneration of various tissue (16). However, whether the umbilical cord-derived MSC conditioned medium also has a positive effect on the peripheral nervous regeneration or not still needs to be proven.

Mesenchymal stem cells (MSCs) are multipotent stromal mesenchymal cells that can renew themselves and can be found in almost every organ and postnatal tissue. Some studies have suggested the use of MSC as a method of alternative therapies because they have the ability to differentiate. Mesenchymal stem cells can differentiate into various cells of the nervous system, such as astrocytes, oligodendrocytes, and Schwann cells (58).

The umbilical cord-derived mesenchymal stem cells (UC-MSCs) were reported to secrete various growth factors including NGF and VEGF, which are important to support Schwann cell proliferation (25). A research mentioned that bFGF, PDGF and VEGF secreting MSC therapies could affect cell biology and increase MSC proliferation as well as change their differentiation potential. VEGF expression was stated to have no difference from MSC control in terms of proliferation or differentiation assays but has significantly greater angiogenic potential in in vitro and in vivo conditions, suggesting that this may be a safe and effective strategy for treating vascular complications $(60,46)$.

Initial researches were done on walking analysis in experimental animals using the sciatic functional index (SFI) measurement method. Measurement using this method requires some supporting data such as print length (PL), intermediary toe spread (ITS), and toe spread (TS) that are put into a specific formula. The initial study examined a faster and more practical method for carrying out a walking analysis that had the same validity and reliability as the previous existing measurement. The measurement performed was the measurement of the angles around the midpoint between PL and TS called Q1, Q2, Q3, and Q4. The research reported that Q1, Q2, Q3, and Q4 measurements showed no significant difference from SFI and TOA results in normal rats. In addition, this research used four different colour inks that have proven in previous researches in facilitating walking analysis (31).

Previous studies have identified the properties of stem cells originating from the umbilical cord (UC-MSCs) (41). The conditioned medium (UC-MSCs) Vascular Endothelial Growth Factor (VEGF) was been detected with Enzyme-Linked Immunosorbent Assay (ELISA) detection method (42). However, the mechanism of conditioned medium of UC-MSCs in the regeneration of acute peripheral nerve injury is still unknown. Therefore, the objective of this research was to investigate the effect and mechanism of UC-MSC conditioned medium on the structure and function of peripheral nerves after injury.

\section{MATERIALS AND METHODS}

This experimental research used rats (Rattus norvegicus) of Sprague-Dawley strain aged 2-3 months with weight ranging from 250-300 grams as experimental animals. The animals were divided into 3 groups, namely one control (Sham) group (SH) and two treatment groups standard therapy (TS) and conditioned medium therapy (CM). The sciatic nerve of the control group (SH) was not injured and was only given the standard treatment. The sciatic nerve of the standard therapy treatment group (TS) was injured and then received standard suturing. The sciatic nerve of the conditioned medium treatment group (CM) was injured and then was given UC-MSC conditioned medium before receiving standard suturing. Repetitions were done 6 times. The research was divided into two stages with 18 rats per stage. The first stage was a short-term research performing check-ups until the 7th day post nerve injury and the second stage was a long-term research by conducting examination until the 70th day post nerve injury.

The research procedure began with a pre-research stage to obtain UC-MSC conditioned medium and the optimization of the making of the experimental animals for the peripheral nerve injury model, and after obtaining a consistent method, the following step was the main research stage. The preparation of the test material of UC-MSC conditioned medium was based on the research conducted by Pawitan et al. in 2014 using a complete medium as culture media (40). After that, the growth factors in the conditioned medium of UC-MSC were measured, and the condition medium was freeze dried (42). The development of experimental animals used micro surgery according to the nerve injury model surgical standard. After the material and experimental animals were obtained, the next step was the main research stage, which comprised, among others, motor, electrophysiological and histological examinations.

\section{Motor Function Analysis}

The motor examination in the short-term research was conducted three times, namely pre-operation, 3 days post injury (dPI) and $7 \mathrm{dPI}$, while for long-term research it was conducted eight times i.e. pre-operation, 3-7-14-28-42-56 and $70 \mathrm{dPI}$. Motor examination was in the forms of walking analysis that measured the SFI, TFI, PFI, Q1, Q2, Q3, Q4 and TOA. 
Table 1: Results of SFI, TFI and PFI

\begin{tabular}{|c|c|c|c|c|c|c|c|c|c|}
\hline \multirow{2}{*}{$\begin{array}{l}\text { Day } \\
\text { (PI) }\end{array}$} & \multicolumn{3}{|c|}{ SFI (SD) } & \multicolumn{3}{|c|}{ TFI (SD) } & \multicolumn{3}{|c|}{ PFI (SD) } \\
\hline & CM & TS & $\mathrm{SH}$ & CM & TS & SH & CM & TS & SH \\
\hline Pre & $-9.65 \pm 2.02$ & $-8.62 \pm 2.10$ & $-10.23 \pm 2.11$ & $-9.95 \pm 2.10$ & $-7.97 \pm 2.18$ & $-11.17 \pm 2.25$ & $-8.79 \pm 6.37$ & $-18.79 \pm 6.03$ & $-15.93 \pm 1.87$ \\
\hline 3 & $-93.30 \pm 0.00$ & $-93.30 \pm 0.00$ & $-17.26 \pm 5.75$ & $-121.60 \pm 0.00$ & $-121.60 \pm 0.00$ & $-17.76 \pm 6.12$ & $-268.60 \pm 0.00$ & $-268.60 \pm 0.00$ & $-26.44 \pm 11.91$ \\
\hline 7 & $-59.53 \pm 30.07$ & $-93.30 \pm 0.00$ & $-21.32 \pm 11.35$ & $-72.78 \pm 42.21$ & $-121.60 \pm 0.00$ & $-21.51 \pm 12.00$ & $-107.78 \pm 125.61$ & $-268.60 \pm 0.00$ & $-20.48 \pm 9.01$ \\
\hline 14 & $-45.05 \pm 26.15$ & $-93.30 \pm 0.00$ & $-13.55 \pm 5.26$ & $-54.83 \pm 35.52$ & $-121.60 \pm 0.00$ & $-15.48 \pm 6.20$ & $-64.47 \pm 101.87$ & $-268.60 \pm 0.00$ & $-20.03 \pm 9.00$ \\
\hline 28 & $-20.96 \pm 8.73$ & $-57.36 \pm 28.13$ & $-11.95 \pm 7.38$ & $-22.01 \pm 7.70$ & $-70.05 \pm 40.13$ & $-12.86 \pm 7.48$ & $-18.82 \pm 3.59$ & $-114.13 \pm 120.17$ & $-13.08 \pm 12.27$ \\
\hline 42 & $-17.71 \pm 8.43$ & $-36.61 \pm 8.31$ & $-13.31 \pm 7.35$ & $-19.96 \pm 9.03$ & $-43.82 \pm 11.95$ & $-13.08 \pm 9.12$ & $-18.27 \pm 7.17$ & $-28.90 \pm 7.141$ & $-20.71 \pm 8.55$ \\
\hline 56 & $-14.89 \pm 6.66$ & $-28.69 \pm 11.22$ & $-16.22 \pm 9.83$ & $-17.31 \pm 6.34$ & $-33.11 \pm 12.42$ & $-17.23 \pm 12.17$ & $-14.58 \pm 7.18$ & $-26.90 \pm 8.18$ & $-18.81 \pm 6.30$ \\
\hline 70 & $-11.67 \pm 1.87$ & $-35.50 \pm 15.09$ & $-10.65 \pm 4.24$ & $-12.41 \pm 2.97$ & $-41.94 \pm 19.38$ & $-11.36 \pm 4.20$ & $-15.01(2.63)$ & $-33.23 \pm 11.51$ & $-11.73 \pm 7.49$ \\
\hline
\end{tabular}

Note: $\mathrm{CM}$ : Conditioned medium group (injured sciatic nerve + standard sutures + conditioned medium); TS: standard therapy group (injured sciatic nerve + standard sutures); SH: normal control treatment group (Sham, uninjured sciatic nerve); SFI: Sciatic Functional Index; TFI : Tibial Function Index; PFI : Perineal Function Index; SD: Standard Deviation

Table 2: Results of Q1, Q2, Q3, Q4 and TOA

\begin{tabular}{|c|c|c|c|c|c|c|c|c|c|c|c|c|c|c|c|}
\hline \multirow{2}{*}{$\begin{array}{l}\text { Day } \\
\text { (PI) }\end{array}$} & \multicolumn{3}{|c|}{ Q1 (SD) } & \multicolumn{3}{|c|}{ Q2 (SD) } & \multicolumn{3}{|c|}{ Q3 (SD) } & \multicolumn{3}{|c|}{ Q4 (SD) } & \multicolumn{3}{|c|}{ TOA (SD) } \\
\hline & CM $\left(^{\circ}\right)$ & TS $\left(^{\circ}\right)$ & $\mathrm{SH}\left({ }^{\circ}\right)$ & CM $\left({ }^{\circ}\right)$ & TS $\left(^{\circ}\right)$ & $\mathrm{SH}\left({ }^{\circ}\right)$ & CM $\left(^{\circ}\right)$ & TS $\left(^{\circ}\right)$ & $\mathrm{SH}\left({ }^{\circ}\right)$ & $\mathrm{CM}\left({ }^{\circ}\right)$ & TS $\left({ }^{\circ}\right)$ & $\mathrm{SH}\left({ }^{\circ}\right)$ & $\mathrm{CM}\left({ }^{\circ}\right)$ & TS $\left({ }^{\circ}\right)$ & SH ( $\left.{ }^{\circ}\right)$ \\
\hline \multirow{2}{*}{ Pre } & 79,83 & 76,33 & 81,80 & 100,17 & 103,67 & 98,20 & 79,83 & 76,33 & 81,80 & 100,17 & 103,67 & 98,20 & 29,64 & 30,77 & 30,12 \\
\hline & $(4,79)$ & $(8,03$ & $(7,50)$ & $(4,79)$ & $(8,03)$ & $(7,50)$ & $(4,79)$ & $(8,03)$ & $(7,50)$ & $(4,79)$ & $(8,03)$ & $(7,50)$ & $(1,98)$ & $(1,39)$ & $(0,52)$ \\
\hline \multirow{2}{*}{3} & 0,00 & 0,00 & 80,53 & 0,00 & 0,00 & 99,47 & 0,00 & 0,00 & 80,53 & 0,00 & 0,00 & 99,47 & 0,00 & 0,00 & 24,19 \\
\hline & $(0,00)$ & $(0,00)$ & $(4,45)$ & $(0,00)$ & $(0,00)$ & $(4,45)$ & $(0,00)$ & $(0,00)$ & $(4,45)$ & $(0,00)$ & $(0,00)$ & $(4,45)$ & $(0,00)$ & $(0,00)$ & $(4,23)$ \\
\hline \multirow{2}{*}{7} & 79,42 & 0,00 & 83,72 & 100,58 & 0,00 & 96,28 & 79,42 & 0,00 & 83,72 & 100,58 & 0,00 & 96,28 & 21,33 & 0,00 & 26,73 \\
\hline & $(6,71)$ & $(0,00)$ & $(6,91)$ & $(6,71)$ & $(0,00)$ & $(6,91)$ & $(6,71)$ & $(0,00)$ & $(6,91)$ & $(6,71)$ & $(0,00)$ & $(6,91)$ & $(4,23)$ & $(0,00)$ & $(2,31)$ \\
\hline \multirow{2}{*}{14} & 79,75 & 0,00 & 84,00 & 100,25 & 0,00 & 96,00 & 79,75 & 0,00 & 84,00 & 100,25 & 0,00 & 96,00 & 21,55 & 0,00 & 27,98 \\
\hline & $(6,40)$ & $(0,00)$ & $(7,90)$ & $(6,40)$ & $(0,00)$ & $(7,90)$ & $(6,40)$ & $(0,00)$ & $(7,90)$ & $(6,40)$ & $(0,00)$ & $(7,90)$ & $(5,01)$ & $(0,00)$ & $(2,24)$ \\
\hline \multirow{2}{*}{28} & 80,86 & 82, & 80,00 & 99,14 & 97,08 & 100,00 & 80,8 & 82 & 80 & 99,14 & 97,08 & 100,00 & 26,81 & 18 & 29,03 \\
\hline & $(2,96)$ & $(8,31)$ & $(7,07)$ & $(2,96)$ & $(8,31)$ & $(7,07)$ & & & & & & & & & $(2,38)$ \\
\hline \multirow{2}{*}{42} & 82,85 & 80,60 & 83,50 & 97,15 & 99,20 & 96,50 & 82,85 & 80,60 & 83,50 & 97,15 & 99,20 & 96,50 & 27,40 & 19,52 & 28,38 \\
\hline & $(4,27)$ & $(6,66)$ & $(5,32)$ & $(4,27)$ & $(6,69)$ & $(5,32)$ & $(4,27)$ & $(6,66)$ & $(5,32)$ & $(4,27)$ & $(6,69)$ & $(5,32)$ & $(2,40)$ & $(6,07)$ & $(2,02)$ \\
\hline \multirow{2}{*}{56} & 78,47 & 78,70 & 83,92 & 101,53 & 100,80 & 96,08 & 78,47 & 78,70 & 83,92 & 101,53 & 100,80 & 96,08 & 27,83 & 21,08 & 27,95 \\
\hline & $(7,50)$ & $(5,83)$ & $(3,25)$ & $(7,50)$ & $(5,53)$ & $(3,25)$ & $(7,50)$ & $(5,83)$ & $(3,25)$ & $(7,50)$ & $(5,53)$ & $(3,25)$ & $(2,41)$ & $(6,51)$ & $(0,91)$ \\
\hline \multirow{2}{*}{70} & 80,86 & 77,10 & 81,40 & 99,69 & 102,90 & 98,60 & 80,86 & 77,10 & 81,40 & 99,69 & 102,90 & 98,60 & 26,82 & 18,94 & 28,00 \\
\hline & $(1,83)$ & $(4,13)$ & $(3,44)$ & $(2,93)$ & $(4,13)$ & $(3,44)$ & $(1,83)$ & $(4,13)$ & $(3,44)$ & $(2,93)$ & $(4,13)$ & $(3,44)$ & $(3,26)$ & $(4,85)$ & $(0,78)$ \\
\hline
\end{tabular}

Note: CM: Conditioned medium group, TS: Standard therapy group, SH: normal control treatment group (Sham); Q1: The angle between the line from the midpoint to the third fingertip and the line from the midpoint to the first finger; Q2: The angle between the line from the midpoint to the first finger and the line from the midpoint to the heel; Q3: The angle between the line from the midpoint to the heel and the line from the midpoint to the fifth fingertip; Q4: The angle between the line from the midpoint to the fifth finger and the line from the midpoint to the third fingertip; TOA: Toe Out of Angel; SD : Standard Deviation

\section{Electrophysiological Analysis}

Electrophysiological examinations were done twice, on the 7th days post injury (dPI) and the $70 \mathrm{dPI}$. The parameters used to measure the physiological response of experimental animals were maximal stimulus, minimal stimulus, conduction velocity, and nerve conduction time.

\section{Histological Analysis}

Histological examination was performed after electrophysiological examination, on the 7 days post injury (dPI) and the $70 \mathrm{dPI}$, by analyzing the structures that were involved in peripheral nerve regeneration, namely connective tissues, myelin sheath, blood vessels and Schwann cells.

\section{RESULTS}

\section{Motor Function Analysis Result}

Based on Table 1, it is known that nerve injury has occurred in all standard and CM groups on the $3^{\text {rd }}$ day after nerve injury. CM group has shown faster recovery on the 14 days post injury (dPI) than the standard group that has only shown nerve injury repair after the $28 \mathrm{dPI}$.

The results of the motor function examination on the rats' footprints showed that the angle formation (Q1-Q4 and TOA) in CM group had occurred on the $7 \mathrm{dPI}$, but in the standard group from the 3 to the $14 \mathrm{dPI}$ there was no angle formation footprints. The angle formation in the standard group only occurred on the $28 \mathrm{dPI}$. These results proved that the footprint angles of rats can be used for motor function examination because the obtained results are in line with SFI, TFI and PFI values (Table 2). 


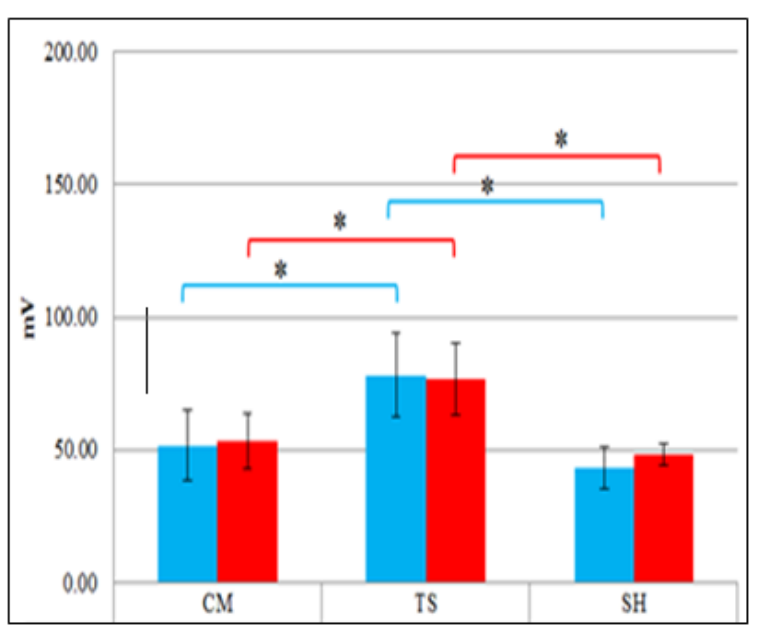

(A)

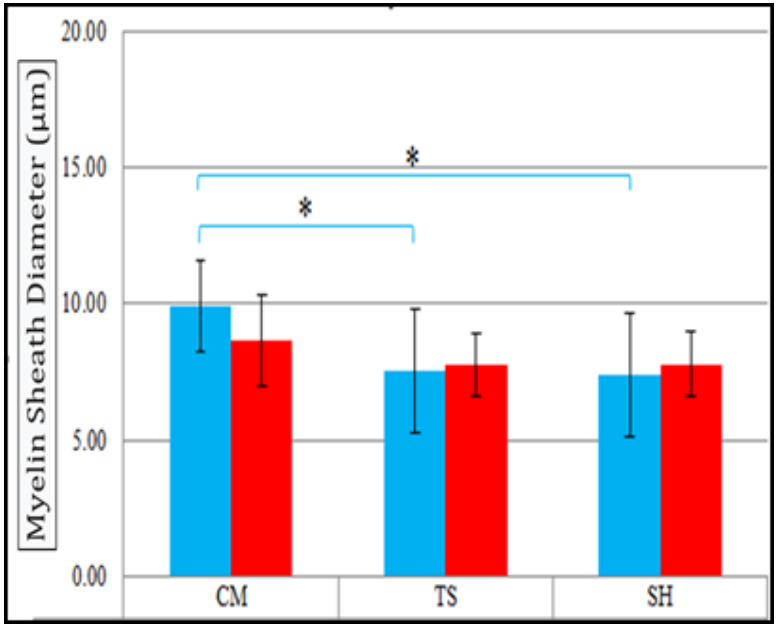

(C)

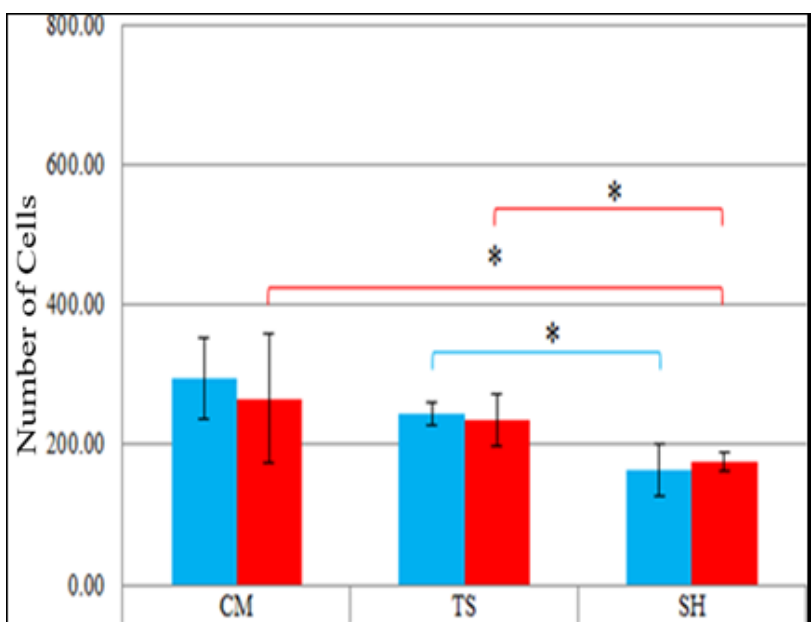

(B)

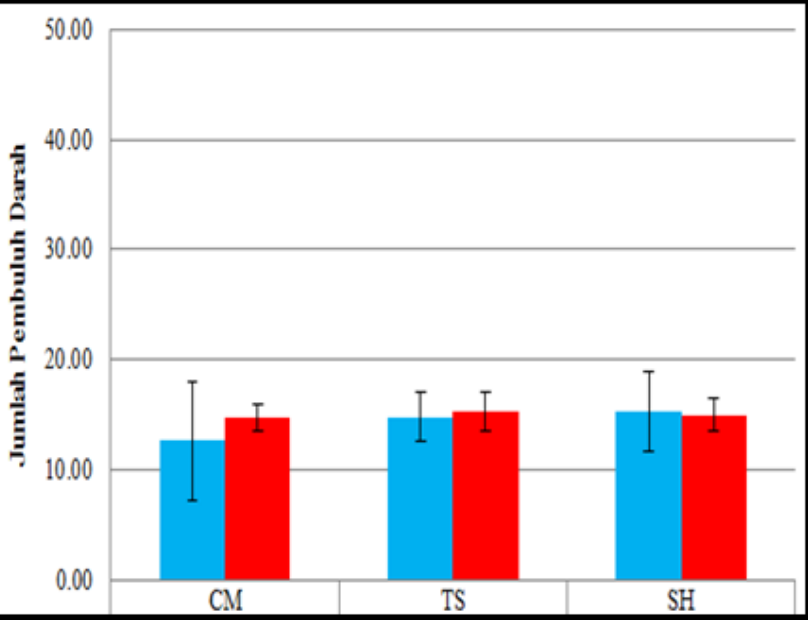

(D)

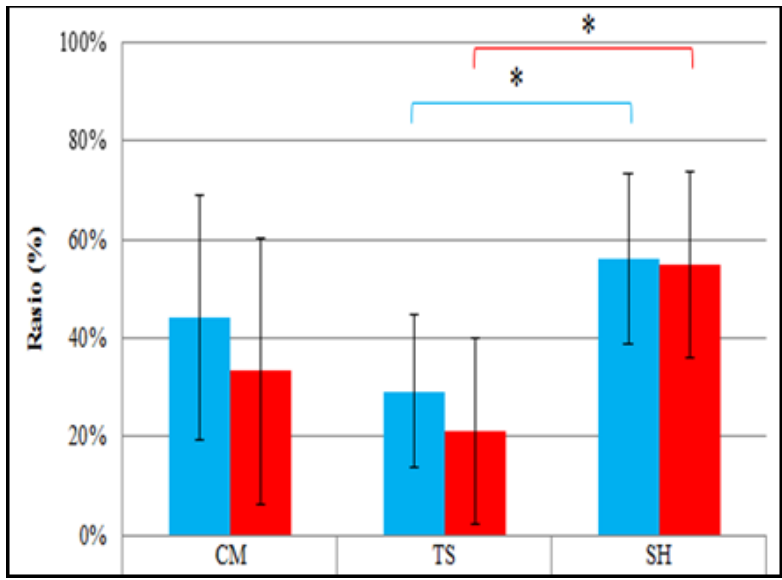

(E)

Figure 1: Bar chart of the electrophysiological $[A]$, the average number of total cells $[B]$, myelin sheath diameter $[C]$, blood vessel quantity [D], and the ratio of Schwann cells to total cells [E] of CM, standard, and sham groups of the left leg of rats on the 7 and 70 days post injury (dPI); Bar chart of latency time between CM, standard and sham groups on the 7 and 70 dPI. CM=conditioned medium, TS=standard therapy, $\mathrm{SH}=$ Control (Sham) group

\section{The Results of Electrophysiological Analysis on the 7 and 70 Days Post Injury (dPI)}

The electrophysiological examination parameter measured was Nerve Conduction Velocity (NCV). The parameter was calculated from the distance between the electrodes on the stimulator and the recorder (in humans the distance from the receptor to the effector) divided by the latency time and the distance between the electrodes on the stimulator and the recorder. Latency time is the time required in the administration of the initial stimulus to the occurrence of combined action potential (PAG). The recording results of the electrical activity of the sciatic nerve, namely the minimal stimulus 

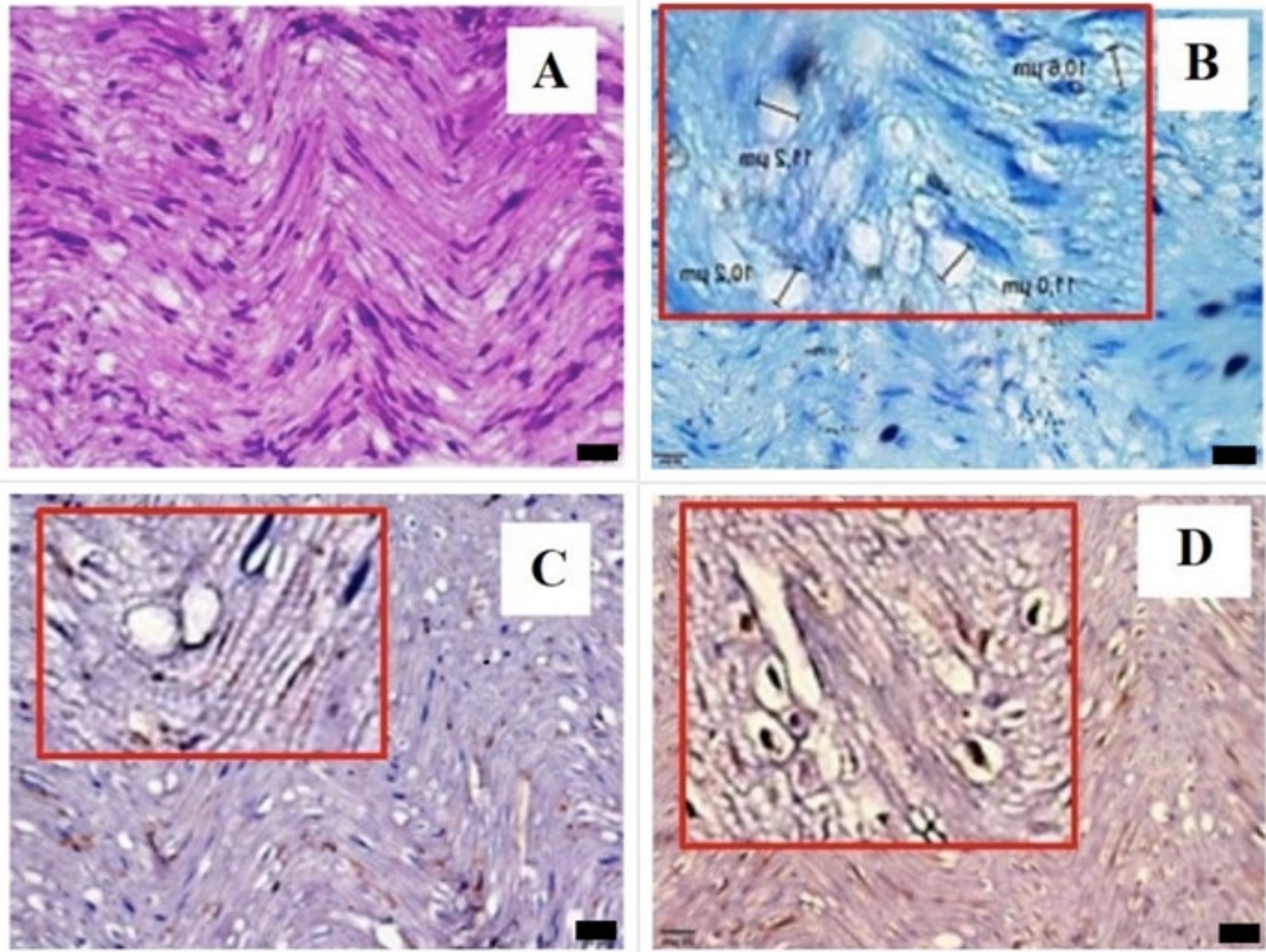

Figure 2: Histological image of peripheral nerve fibers with HE staining [A]; Myelin sheath diameter with trypan blue staining [B]; Blood vessel quantity with IHK CD34 staining [C]; The ratio of Schwann cells (IHK S100 staining) to total cells [D] of CM group on the 7 days post injury (dPI); 40x magnification. Scale bar, $50 \mu \mathrm{m}$

threshold that could produce the smallest PAG, the maximal stimulus that could cause the highest PAG, the conduction velocity (NCV) and latency time on the 7 days post injury (dPI) and $70 \mathrm{dPI}$ that can be seen in the CM group's minimal stimulus results were quite low in the range of $40-60 \mathrm{mV}$ (lower) than the standard groups (>70mV). The minimal stimulus is the minimum electrical activity required to generate the smallest combined action potential. Therefore, $\mathrm{CM}$ group had better electrical activity because with the smallest stimulus CM group could trigger the occurrence of combined action potential. This fact proved that the sciatic nerve in $\mathrm{CM}$ and sham groups was more sensitive to electrical stimulation compared to the standard group on the 7 as well as the $70 \mathrm{dPI}$. The maximal stimulus result is the maximum electrical activity required to achieve the highest combined action potential. Therefore, $\mathrm{CM}$ and sham groups had a higher maximal stimulus to achieve combined action potential than the standard. This fact proved that the sciatic nerve of $\mathrm{CM}$ and sham groups was more sensitive to stimulation (reaching combined action potential) compared to the standard group on the 7 and $70 \mathrm{dPI}$.

The results of nerve conduction velocity (NCV) showed that the conduction velocity of $\mathrm{CM}$ group was close to normal (sham) than the standard group on the 7 and $70 \mathrm{dPI}$. This fact proved that CM group was capable of delivering nerve conduction (reaching combined action potential) better than the standard group on the 7 and $70 \mathrm{dPI}$. The results of latency time are used to determine the time required in the administration of the initial stimulus until the occurrence of combined action potential (PAG). Therefore, CM and sham groups had a faster latency time to achieve combined action potential than the standard group. This fact proved that the sciatic nerve of $\mathrm{CM}$ and sham groups was more sensitive to stimulation (reaching combined action potential) compared to the standard group on the 7 and $70 \mathrm{dPI}$.

\section{Histological Analysis Results}

The result of the histological analysis image was showed in Figure 2. The structures that were involved in peripheral nerve regeneration was showed by the histological structures of peripheral nerve fibers (Figure $\mathbf{2 A}$ ), myelin sheath (Figure 2B), blood vessels (Figure 2C), and Schwann cells (Figure 2D). The results showed that the CM group had higher cell growth compared to the standard group. CM group had a high mean of myelin sheath diameter compared to the 
standard or sham groups on the $7 \mathrm{dPI}$. The CD34 expression for the number of blood vessels in the CM group was smaller compared to the standard or sham groups. The S100 expression in the CM group was found being expressed higher compared with the standard group.

\section{DISCUSSION}

\section{UC MSC Conditioned Medium}

Conditioned medium (CM) in this research was derived from the mesenchymal stem cells of human umbilical cord. The selection of stem cells for the making of conditioned medium was based on the research conducted by Pawitan et al. (2017). The selection of human mesenchymal stem cells was based on several reasons including the consideration of cell quantity, and the accessibility of sample. Human mesenchymal stem cells can be derived from various sources, namely the bone marrow, adipose tissue, umbilical cord and so on (24). From several sources, it is known that the isolation percentage of the adipose-derived mesenchymal stem cells is higher than that of the bone marrow or that of the umbilical cord with the isolation percentage of adipose tissue higher to the bone marrow, which is $100 \%$. However, the umbilical cord-derived mesenchymal stem cells have a much higher proliferation and differentiation potentials, especially when compared with bone marrow-derived and adipose-derived mesenchymal stem cells $(24,26)$. In addition, the umbilical cord-derived mesenchymal stem cells are also easily isolated from post-natal tissues that are not used after birth so there is no significant ethical issue (24).

The mechanism of stem cells in peripheral nerve regeneration as the initial response to nerve injury is to differentiate into cells similar to Schwann cells that can recruit macrophages to clean up the debris during the Wallerian degeneration process. Next, Schwann cells secrete neutrophic (growth) factors that can increase the growth of axons and remielinization $(16,20,53)$. This research used the umbilical cord-derived mesenchymal stem cells (UC MSC) of which the environment had been conditioned in such a way to obtain the factors supporting nerve regeneration. The research of Pawitan et al. (2017) mentioned that UC MSC conditioned medium contained many growth factors such as EGF, VEGF, NGF and PIGF. The growth factors were mostly detected after the third day of harvest, and the results was used as the test material (conditioned medium) in this research.

The umbilical cord-derived mesenchymal stem cells (UC MSC) can differentiate into cells similar to human Schwann cells. These cells produce neurotrophic factors (growth), namely neurotropin, neuregulatory cytokine, TGF- $\beta$, GDNF, EGF, PDGF, (17) BDNF and NGF (16) that are useful in the defense of neural cells and neurogenesis. The research of Zarbakhsh et al. (2016) has revealed that the Schwann cell-like cell differentiation resulting from UC MSC culture transplanted in sciatic nerve injury through immunosuppression (maintaining the phenotype) functionally has the same results as the original Schwann cells based on the walking analysis. This suggests that the umbilical cord-derived mesenchymal stem cells can be used to produce Schwann-like cell cells for nerve regeneration therapy. In addition, the growth factors produced by mesenchymal stem cells in cultures are known to have various benefits in regenerative medicine, one of them is for nerve regeneration therapy. The concentrations of VEGF and NGF were the focus in this research due to their benefits in regenerating nerve cells.

The addition of growth factors to cell cultures in vitro can directly trigger proliferation by inducing cell division cycles and enhancing the cell's ability to survive (30). NGF growth factor can improve the process of myelination in the peripheral nerves mainly to stimulate the Schwann cells to proliferate (44). In addition, NGF also plays an important role in axon regeneration, especially to increase the growth of axons (51).

VEGF functions to create new blood vessels (neovascularization) after nerve injury and to increase vascular permeability, Schwann cell proliferation, the survival of endothelial cells and the formation of new blood vessels from existing blood vessels (angiogenesis) in the connective tissue sheath $(15,23)$. Pereira et al. (2008) reported that VEGF gene therapy can enhance nerve regeneration process by increasing vascularity, myelination and nerve functions.

\section{Injury Type and Suturing Method}

Sciatic nerve treatment groups (CM and standard) experienced neurotmesis injury type, which is injury caused by transection (36). The injury is the third degree injury according to the Seddon classification and the fifth degree injury according to the Sunderland classification. In this type of injury, the sciatic nerve was cut to separate the layers of anatomical structures such as the epineurium, perineurium, and endoneurium until split into two. The cut causes disruption to all nerve structures, especially disorders of nerve conduction, motor function and sensory nerves. According 
to the Sunderland classification, neurotmesis causes axons, myelin and connective tissue to become impaired or damaged (48).

The results showed that $\mathrm{CM}$ and standard groups suffered from sciatic nerve injury on the 3 and 7 th day after surgery. The injury can be seen from the motor function index values of SFI, TFI, and PFI, which show values approaching -100 . $\mathrm{SFI}, \mathrm{TFI}$ and PFI values approaching -100 have proven that damages existed and no regeneration occurred on the sciatic nerve $(4,6,52)$. Injury recovery from transection (neurotmesis), according to Rubin and Herman (2007), is effectively very rare and even impossible, depending on the severity of the severed nerve. New peripheral nerve regeneration will occur after the 5th day towards the 7th day post operation, which is marked by axon growth rate of $\sim 1 \mathrm{~mm}$ per day or $\sim 1$ inch per month $(9,36)$.

The success of peripheral nerve regeneration is also determined by the method of suturing post-nerve injury. The suturing method in this research used end-to-end suture. The method was consistent with the operating protocol in peripheral nerve-injured rats. The suturing position was in the direction of 1, 5 and 9 o'clock in accordance with the standard research procedure. After nerve injury due to transection, the suturing process is important to combine the proximal and distal ends of epineurium.

Generally, after suturing, effective functional repair of the nerves is very rare. This is evident from the research results pointing out that the sciatic nerve repair in the standard group showed mediocre results up to 70 days post injury (dPI) less than CM group. The motor function in the standard group only showed improvement on the $28 \mathrm{dPI}$. Meanwhile, CM group that was given the UC-MSC conditioned medium therapy showed faster improvement, which was on the $7 \mathrm{dPI}$. This suggests that suturing or surgery was less effective for peripheral nerve regeneration; it requires considerable time for nerve regeneration to occur effectively (8).

\section{Motor Function Analysis}

Researches on peripheral nerve injury generally use several parameters to analyze motor function $(14,35)$. Bain et al. (1988) used motor function parameters such as print length (PL), intermediary toe spread (ITS) and toe spread (TS) to determine SFI, TFI and PFI values. Recent researches stated that the parameters Q1-Q4 and TOA can also be used to analyze motor function. The research results of Margiana et al. (2015) showed that the angle Q1-Q4 and TOA have in line results with the SFI value in normal rats. Therefore, this research used not only SFI, TFI and PFI but also Q1-Q4 and TOA as motor function parameters in sciatic nerve-injured rats.

Rat footprint analysis using PL, ITS and TS can be and has been used in several studies of peripheral nerve regeneration to measure motor function, namely the sciatic functional index (SFI), tibia functional index (TFI) and peroneal functional index (PFI) (6). Rats are said to have normal PL analysis when PL is short, so rats are walking using their nails. In contrast, rats experiencing nerve injury or damage will walk on all the soles of their feet (treading) on the ground/floor and sometimes drag their feet when walking (35).

The normal values of SFI $(56,57) \mathrm{TFI}$ and PFI were approaching 0 ; the numbers closer to -100 indicate the occurrence of lesion on the nerve or non-occurrence nerve regeneration $(4,52,56,57)$. From the research results, it is known that SFI, TFI and PFI values in the sham group had a range of values of -26.44 to -10.23 . These values could be used as normal control for $\mathrm{CM}$ and standard groups.

SFI examination results in this research are consistent with several studies about the sciatic functional index (SFI) using different methods with the same type of animals; note that the SFI results obtained SFI had different outcomes $(34,38)$. The administration of UC MSC conditioned medium in CM group succeeded in improving motor function (SFI, TFI and $\mathrm{PFI}$ ) on the $7 \mathrm{dPI}$ with the repair closest to normal control on the $70 \mathrm{dPI}$. Structurally, the nerve injury in CM group has improved on the $70 \mathrm{dPI}$. This supports the research conducted by Silva et al. in 2010 on sciatic nerve-injured rats, which were given fibrin glue treatment, where after 90 days post nerve injury, SFI value approaches normal rate after a given treatment, but on 30th day after nerve injury there was no significant improvement (52).

However, improvement in the standard group did not happened until the $28 \mathrm{dPI}$. It can be seen from SFI, TFI and PFI values showing numbers close to -100 , which is categorized as the condition where nerve regeneration has not occurred (abnormal). Until the $70 \mathrm{dPI}$, standard group still did not show significant repair approaching the motor function values of sham group. This was likely due to the fact that the standard group experienced neurologic deficits, meaning that they structurally improve, but their motor functions have not. Based on the results of motor function in this research, it can be said that the motor function repair is faster in CM group ( $7 \mathrm{dPI}$ ) compared to the standard group ( $28 \mathrm{dPI}$ ). The administration of UC MSC conditioned medium is able to affect motor function repair in sciatic nerve injury. 
Generally, sciatic nerve in rats have three branches, namely tibial nerve, common peroneal nerve and sural nerve. All three branches have different functions in supplying lower extremity part. Tibial nerve functions to innervate the tibialis anterior muscle responsible for movement of the dorsi muscle and the flexion of the legs. When an injury occurs, it can cause the tibialis anterior muscle to become weak and the movement will be limited. Tibial nerve has two branches, namely the lateral plantar nerve and the medial plantar nerve. The lateral plantar nerve functions to innervate the lateral part of the legs including the intersseous muscles responsible for the function of adduction. Meanwhile, the medial plantar nerve serves to regulate the movement in the medial part of the legs $(5,10,18,50)$.

The malfunctions of the two branches of tibial nerve were seen in the results of this research showing that TFI index had a value close to -100 in $\mathrm{CM}$ and standard groups on the 3 and $7 \mathrm{dPI}$. The disturbances on the lateral plantar nerve and medial plantar nerve have caused disorder on the third finger and the line connecting between the first and fourth fingers in rats $(5,6,50)$. Disturbances in both nerves have led to the limited leg movement of the rats. Meanwhile, the peroneal nerve disorder can be seen from the value analysis of PFI which is responsible for the extremity function of the legs/dorsal region of legs. The results showed that the PFI values of CM and standard groups also pointed out injury on the 3 and $7 \mathrm{dPI}$.

In addition to motor function measurements using SFI, TFI and PFI methods, Q1-Q4 angle measurements have been done in this research. The measurement results of rat footprint angles can be used to analyze the motor function of the experimental animals. This is evident from the result similarities between Q1-Q4 and SFI on the motor function of normal rats (31). The experimental research conducted by Varejao et al. (2001) using foot angle measurement parameter (TOA) has also had good correlation with SFI (35).

Based on the sensitivity and specificity values between the walking function of SFI, TFI and PFI and the rat footprint angles of Q1-Q4 and TOA, it is known that the sensitivity percentage was very high which was $\geq 90 \%$ and the percentage of specificity between both reaching $100 \%$. The determination of sensitivity and specificity values was based on the normal and abnormal value criteria of $\mathrm{CM}$ or standard groups compared to the sham group. The results of the sensitivity and specificity values that showed numbers above $90 \%$ up to $100 \%$ have proven that motor function measurements using SFI, TFI and PFI have similar results with the measurement using the footprint angles of Q1-Q4 and TOA. The results of this study are in tune with the research reported by Margiana et al. (2015).

\section{Electrophysiological Analysis}

Electrophysiological examination was carried to determine the ability of sciatic nerve in delivering electrical conduction. The ability of sciatic nerve to deliver electrical conduction was detected through minimal stimulus, maximal stimulus, nerve conduction velocity (NCV) and latency time value parameters that were recorded. Electrophysiological examination resulted in minimal stimulus to achieve the combined action potential that was quite large in the standard group than CM group as well as the sham group. CM Group was able to achieve combined action potential with a fairly low minimal stimulus. This has proven that the sciatic nerve in $\mathrm{CM}$ group has better response to achieve minimum combined action potential compared to that of the standard group. The administration of UC MSC conditioned medium had a significant influence on the examination on the 7 and the $70 \mathrm{dPI}$ against the electrical activity of the sciatic nerve in CM group.

The action potential or electrical impulses can cause a voltage difference (voltage) on the membrane. Axon membrane depolarization occurs as a result of the provision of electrical impulses in nerve cells. As is known, nerve cells are very sensitive to stimulation and are capable of delivering and responding quickly and constantly to electrical signals. The factor of ions on the membrane is one that affects the membrane action potential. The ion $\mathrm{Na}+$ enters the cell at a fast rate and $\mathrm{K}+$ exits the cell to maintain charge balance. During the resting state, the nerve cell membrane is only slightly permeable to the ion $\mathrm{Na}+$; if the membrane is given a stimulus, $\mathrm{Na}+$ will move into the cells following the electrochemical gradient resulting in cell membrane depolarization and generating electrical signal. The electrophysiological results obtained at maximal stimulus examination showed that the standard group could not reach combined action potential (PAG) as well as CM group. CM group could achieve PAG that was almost equal to the sham group on the $70 \mathrm{dPI}$. This has proven that the sciatic nerve of CM and sham groups is more capable in achieving PAG than the standard group.

Conduction velocity depends on fast signal propagation on the nerves. Electrical conduction in the nerves produces depolarization wave in the axon and combined action potential propagation in both directions of axon endings. The combined action potential obtained was derived from the cathode and anode that were placed at a distance adjacent to each other. The signal propagation speed is made possible by the process of myelination. Myelination is capable of delivering faster electrical conduction. In contrast, the demyelinating process generally indicates a decrease in nerve 
conduction velocity. The process of demyelination can occur in the peripheral nerve that suffers an injury, hence there was low nerve conduction velocity in the standard group (11). Electrical stimulation with a duration of 0.1 ms was used to activate the myelination on the nerve fibers with the stimulus strength adjusted to achieve the maximum response; but it still needs further researches to prove it (39).

The latency time results showed that the standard group required considerable time to deliver electrical impulses or electrical activity compared with the sham and CM groups. The sciatic nerve on CM group was capable to deliver electrical impulses more quickly, thus combined action potential can be easily achieved.

\section{Motor Functions and Electrophysiological Analysis of the Sciatic Nerve}

One of the factors that affect the propagation of nerve conduction is determined by the presence of ion channels in the cell membrane that are alternately opened and closed. Ion channels allow the ions that are responsible for the propagation velocity of nerve conduction to move across the membrane during combined action potential. According to Fletcher (2008), action potential conduction requires several types of ion channels, namely the ion channels of $\mathrm{Na}+$ and $\mathrm{K}+$. The channels alternately open and close to change the membrane permeability against $\mathrm{Na}+$ and $\mathrm{K}+$ and then trigger the action potential. $\mathrm{Na}+$ channel is known to play an important role not only for the nerve regeneration but also to trigger action potential conduction in nerve membranes. In addition, it is known that $\mathrm{Na}+$ channel is used as pharmacological target in the treatment of pain sensation (19).

The research results showed that the walking analysis of $\mathrm{CM}$ group indicated that $\mathrm{CM}$ group heals faster than the standard group. The walking analysis of $\mathrm{CM}$ group has shown an improvement on the $7 \mathrm{dPI}$ compared to the standard group that only showed an improvement on the $28 \mathrm{dPI}$. These results may be caused by the sciatic nerve conduction repair of CM group on the $7 \mathrm{dPI}$. UC MSC conditioned medium in CM group can affect the conduction velocity of the sciatic nerve post-injury.

Nerve regeneration did not run well in the standard group due to sciatic nerve injury. It was caused by the process of myelination in the standard group that did not go well like the one in CM group. Myelination allows the propagation of electrical impulses to run quickly, because the myelin sheath is able to prevent the electrical impulses from coming out of the axon membrane.

The research results in the standard group showed that nerve regeneration occurred after $70 \mathrm{dPI}$ but the results were not as good as CM and sham groups. This was likely due to the effects of trauma or injury that cannot be healed to a normal state as before the nerve injury. Disorders such as neurological deficit were likely to occur in the standard group after 70 days of nerve injury. The disorder caused pain or defect in rats. Based on the motor function values and the electrophysiology of the sciatic nerve, on the 70th day the standard group did not show significant improvement compared to CM and sham groups. These results might be connected with ion channels associated with pain after nerve injury. Some studies have revealed that one of the ion channels that plays a role in the healing therapy of post nerve injury trauma is $\mathrm{HCN}$ channel. However, this research does not reveal the role of $\mathrm{HCN}$ channel in the nerve regeneration therapy. Therefore, further research is needed to reveal it.

\section{Total Cell Number}

When a peripheral nerve injury occurs, the cells on sciatic nerve increase, particularly Schwann cells. The sciatic nerve total cell number count used HE staining. The staining can stain all cells with nucleus. Cells that are abundantly found in the sciatic nerve are called Schwann cells. The results showed that CM group produced averagely high total cell count on the 7 and $70 \mathrm{dPI}$ compared to the standard and sham groups on the same day. Growth occurred quite rapidly in CM group even exceeding the normal value in the sham group. This quite high cell growth might be caused by a sciatic nerve injury factor experienced by $\mathrm{CM}$ and standard groups. This fact was in response to the preparation of nerve regeneration process. Subsequently, Schwann cells began releasing neurotrophic factors (growth factors) needed to regenerate nerves.

Based on this research results, CM group had a higher cell growth compared to the standard group; it was likely caused by a growth factor (NGF) contained in the UC MSC conditioned medium that contribute to improving the proliferation of cells, particularly Schwann cells. Moreover, the neurotrophic factor (NGF) is also produced naturally by the Schwann cell body as a factor driving the increased proliferation of Schwann cells and Schwann cell receptors as well as nerve regeneration, mainly axon regeneration (36). 


\section{Myelin Sheath Diameter}

Nerve conduction velocity is determined by several factors, among others is the myelin sheath. Myelin sheath that was found more in $\mathrm{CM}$ group may explain why the nerve conduction velocity in $\mathrm{CM}$ group was higher than that in the standard group. Nerve conduction velocity depends on fast signal propagation made possible by the presence of myelin sheath. Myelinated axons are known to deliver signals faster than unmyelinated axons; unmyelinated axons tend to produce a relatively slower velocity $(3,49)$. This has proven that conditioned medium is able to improve the myelination process on axons so that the signal propagation velocity can be much faster.

Nerve conduction velocity occurs faster in myelinated axons. This is because the myelinated axons have a high resistance to the leakage of electric current coming out of the cells. Myelinated axons can limit the membrane from direct contact with extracellular fluid. The propagation of electrical signals from the trigger zone towards the distal region of the axons passes through the myelinated axons and Nodes of Ranvier that are intermittent (11). Myelinated axons have $\mathrm{Na}+$ and $\mathrm{K}+$ ion channels, which play an important role in the propagation of combined action potential. $\mathrm{Na}+$ channel in myelinated axons is concentrated on every node that is opened during the state of depolarization. It allows $\mathrm{Na}+$ to enter the axons. $\mathrm{K}+$ channel also plays a role in determining the resting membrane potential and combined action potential repolarization. $\mathrm{N}+$ and $\mathrm{K}+$ channel arrangement retains the constant combined action potential amplitude when passing through the nodes to the nodes $(11,32,55)$. Meanwhile, for the unmyelinated axons, $\mathrm{Na}+$ and $\mathrm{K}+$ channels have to open in sequence along the axon membrane to maintain the combined action potential amplitude, so the nerve conduction is slower than that in myelinated axons.

Schwann cells are not only determined by the phenotype of myelinated or unmyelinated axons. Schwann cells in the sensory or motor nerve branches show a different expression against the molecular markers that contribute to the capacity of some axons specifically in nerve regeneration path. The fact indirectly suggests that Schwann cells redifferentiate after nerve injury and loss of specific marker expression on their phenotype, but they need some supporting factors. One of the factors necessary to support Schwann cells are the neurotrophic factors (NGF, VEGF). After nerve injury, the neurotrophic factor expression will increase. This plays a role in the defense and the growth of axon regeneration (3).

The examination of myelin sheath diameter showed that the diameter of the myelin sheath in $\mathrm{CM}$ group had a quite high mean value compared to the standard and sham groups on the $7 \mathrm{dPI}$ as well as the $70 \mathrm{dPI}$. Zhang et al. in 2008 reported that myelin starts to grow on the 2nd day after nerve injury and reaches its peak on the 7th day post-surgery (51). These results have proven that the myelin sheath diameter also plays a role in peripheral nerve regeneration process in CM group.

\section{Blood Vessel Quantity}

The marker in this study was CD34, which is a neovascularization marker. We found that CD34 was expressed lower than the standard group, even though the ANOVA test showed no significant difference. This was likely due to the fact that the VEGF level in UC MSC CM showed less content compared to other growth factors $(1.13+3.88 \mathrm{pg} / \mathrm{mL})(42)$.

As is known, VEGF is a growth factor that is very important in the mechanism of neovascularization (7). VEGF plays an active role in the vascular tissue, therefore VEGF also has a positive effect on nerve regeneration (51). The low expression of CD34 showed the small influence of UC MSC CM on neovascularization occurrence. However, it indicates that UC MSC $\mathrm{CM}$ is safer for patients with cancer or occult cancer, since VEGF can improve vascularization and cancer progression. A research stated that CD34 endothelial progenitor (of adipose-derived MSC) can increase the progression of cancer as a result of paracrine secretion.

Our results showed that the number of blood vessels that expressed CD34 in CM group was small enough compared to the standard or sham groups. Based on a multiple comparison test (post hoc), it was shown that blood vessel number in $C M$ group had no significant difference with the standard and sham groups. This was likely because the concentration of VEGF in conditioned medium was relatively low, hence VEGF expression was low in CM group. This research used VEGF dose as much as $1: 13 \pm 3.88 \mathrm{pg} / \mathrm{ml}(1: 13 \mathrm{ng} / \mathrm{ml})$. The dose contained not only VEGF, but also other growth factors (42). The use of this dose was caused by a technical reason during the research. The research by Hobson et al. In 2000 used laminin-based gel (Matrigel) and VEGF (500-700 ng/ml) in rats with sciatic nerve injury has been known to increase the number of Schwann cells, blood vessel diameter and axons (21). The use of VEGF allows the penetration of blood vessels around the nerve cells and increases the migration of Schwann cells and improvement in nerve regeneration (51). The research by Mohammadi et al. (2013) has stated that the optimum/effective dose in rat nerve regeneration ranges from $10 \mathrm{ng} / \mathrm{ml}$. Thus, if VEGF dose is increased, it will likely give a better effect on nerve regeneration. 
Based on the research results, VEGF dose was still relatively small when compared with similar researches; therefore, further research needs to be done for a higher dose of VEGF, to see whether it can improve peripheral nerve regeneration when the dose is increased. In addition, the less expressed VEGF was also likely caused by other factors; thus, blood vessel quantity was less developed in CM group, namely the presence of the limiting factor (VEGF inhibitor) in the matrix extracellular environment.

Matrix extracellular environment plays an important role in the regeneration of axons. In the peripheral nerve it is known that Schwann cells and fibroblasts produce some of the components of the endoneurial extracellular matrix under the control of axons that can stimulate or inhibit axon regeneration. The component of the extracellular matrix of the peripheral nerves can be divided into two categories: proteoglycans and glycoproteins $(3,36)$.

The example of proteoglycans in the peripheral nerve is chondroitin sulfate proteoglycans (CSPGs). This component is found in the Schwann cell basal lamina. After peripheral nerve injury, CSPGs are able to increase the molecular activity of axon growth and eliminate inhibitor molecule (13). However, in the research it was discovered that in the post central nerve injury the level of overload neurite-inhibitory GSPGs can quickly accumulate in the endoneurial tissue surrounding the basal lamina; therefore, it can have a negative effect on axon regeneration $(13,62)$. In the meantime, some of the components of glycoproteins such as collagen, fibronectin and laminin also play an important role in the regeneration of axons. Collagen plays a role in axon marker (path finding) and synaptic connection. Meanwhile, fibronectin improves the regulation of post peripheral nerve injury $(3,13,36)$.

The research by Akassoglou et al. (2002) has revealed the existence of environmental factor namely fibrin that can inhibit peripheral nerve regeneration because it inhibits axon remyelination. Fibrin inhibits axon remyelination process through the regulation of Schwann cell differentiation. During peripheral nerve injury, there is damage to the bloodnerve barrier that causes the introduction of fibrinogen component into the nerves. Fibrinogen entering the nerves has previously been converted to fibrin via the activation of the coagulation path (7). Fibrin induces the phosphorylation of ERK1/2 and produces the inhibiting factor of p75 NGF low-affinity receptor on Schwann cells and maintains it on unmyelinated axons, thus the remyelination process becomes blocked. ERK $1 / 2$ signaling path plays an important role in the regulation of cell growth and differentiation (27). The Schwann cells cultured for 3 days in fibrin medium showed increased phosphorylation of ERK $1 / 2$ compared with Schwann cells cultured on laminin medium (2). It shows that there is an environmental factor role particularly fibrin that can inhibit peripheral nerve regeneration.

In addition to inhibiting the remyelination process, fibrin also suppresses the production of fibronectin and prevents myelin protein synthesis (P0). During the development and regeneration of nerve, fibronectin level increases. This causes an increase in the migration of Schwann cells, but due to the influence of fibrin, which controls Schwann cells at the proliferation stage, it is possible to affect the inhibition of fibronectin expression and trap the Schwann cell migration (2).

When there is an injury, fibrin regulates Schwann cells through two main channels, namely the phosphorylation of ERK $1 / 2$ and upregulation of p75 NGFR. The combination of the action increase in the proliferation path of ERK $1 / 2$ and the apoptosis path of p75 NGFR enables Schwann cells to become unmyelinated. This is evident by the decline of the myelin transcription factor namely $\mathrm{P} 0$ and fibronectin transcription factor regulation. However, when regeneration occurs, fibrin will be degraded and then ERK $1 / 2$ path becomes unphosphorylated and P75 NGFR regulation decreases, fibronectin is produced and deposited on the nerve and Schwann cells, and remyelination initiation occurs (2).

Peripheral nerve regeneration begins with the Wallerian degeneration process. A cell that was important in the process is macrophages. The roles of macrophages in peripheral nerve regeneration are, among others, cleaning the nerve damage residual debris (phagocytosis), enhancing nerve regeneration by secreting IL-1 that induces NGF expression and improving NGF receptor density in the Schwann cells, which make Schwann cells to be able to secrete many growth factors (mitogenic) to proliferate. However, the macrophages also secrete the antagonist IL-1 receptor that can degrade axon regrowth when applied through a tube implantation in the sciatic nerve-injured rats (36).

This research did not examine the involvement of matrix extracellular environment in regenerating the sciatic nerve so that the influence caused cannot be known. Further research is needed to determine the effect of the extracellular matrix environment in regenerating injured nerve especially sciatic nerve.

\section{Ratio of Schwann Cell to Total Cell Number}

Schwann cells play an important role in peripheral nerve regeneration $(24,59)$. Schwann cells play a role in triggering the occurrence of axon regeneration as a major source of neurotrophic factor (NGF) which can interact with the receptor tyrosine kinases to alter gene expression in neurons that can trigger regeneration (36). In addition, Schwann cells also 
develop a micro-environment that is conducive to the regeneration of axons through the interaction with surrounding extracellular matrix to stabilize the myelin to a normal state (24).

Examination of the ratio of Schwann cell to total cells used S100 marker. The marker is a marker for Schwann cells (45). In the research results, S100 was found being expressed higher in CM group compared with the standard group. Based on the ANOVA test, a significant difference in the analysis of 70 days post injury (dPI) was found, but there was no significant difference in the analysis of $70 \mathrm{dPI}$. This is likely due to the NGF level in UC MSC CM that really showed a fairly high level compared with other growth factors $(21.64+23.70 \mathrm{pg} / \mathrm{mL})(42)$.

In normal circumstances (no injury), NGF level had a lower expression compared to when injury occurred. The high expression of NGF when injury occurred was because NGF can promote the growth and proliferation of Schwann cells as well as Schwann cell receptor that facilitates axon growth. Therefore, the high expression of Schwann cells on $7 \mathrm{dPI}$ was likely due to the peak of Schwann cell proliferation occurring on the $7 \mathrm{dPI}$. This is in line with the research report made by Zhang et al. (2008), stating that the number of Schwann cells began to increase on the 4th day after nerve injury. Later on, the number started to decline on the 21 st day. These results led to the uncommonly found proliferation of Schwann cells on the $70 \mathrm{dPI}$.

During nerve injury, NGF in UC MSC conditioned medium possibly gave an impact on increasing the number of Schwann cell proliferation, improved cell survival through apoptosis prevention mechanism and promoted regeneration factor on neurons and Schwann cells. The growth factor has multiple paths to encourage the regeneration process. One of them is through the entry into the signaling path such as MAPK path, PI3K/Akt, which can encourage Schwann cells to enter the cell cycle until the Schwann cell proliferation can occur. In the cell cycle control, the most instrumental factor is the kinase enzymes, especially cyclic-dependent kinase 2 (Cdk2), which is an important factor of the transition from G1 phase to $S$ phase $(1,54)$.

\section{CONCLUSION}

UC MSC conditioned medium could improve the regeneration of peripheral nerve structure and function after injury. The mechanism of UC MSC conditioned medium in influencing the regeneration of peripheral nerve structure and function after injury was through the increase in Schwann cell proliferation.

\section{ACKNOWLEDGEMENT}

The Principal author acknowledges Dr. Santoso Gunardi as Senior and Old Chief of Departement of Anatomy, Dr. Isabella Kurnia Liem, MBiomed, PhD, PA as Chief of Department of Anatomy, dr. Gondo S. Gozali, PAK, Sasanthy Kusumaningtyas, Ssi, MBiomed, dr. Rahmadini, MBiomed, Deswaty Furqonita, Ssi, MBiomed, drg. Haamid Hasan Haikal, MS as Anatomy Departement staff, and all the member of Anatomy Department.

\section{FUNDING}

The first author is the funders of this research.

\section{REFERENCES}

1. Aguilar V, Fajas L. Cycling through metabolism. EMBO Molecular Medicine, 2010:338-48. https://doi.org/10.1002/emmm.201000089 PMid:20721988 PMCid:PMC3118222

2. Akassoglou K, Yu WM, Akpinar P, Strickland S. Fibrin inhibits peripheral nerve remyelination by regulating schwann cell differentiation. Cell Press, 2002;33:861-75. https://doi.org/10.1016/s0896-6273(02)00617-7

3. Allodi I, Udina E, Navarro X. Specificity of peripheral nerve regeneration: interactions at the axon level. Progress in Neurobiology, 2012;98:16-37. https://doi.org/10.1016/j.pneurobio.2012.05.005 PMid:22609046

4. Amniattalab A, Mohammadi R. Functional, histopathological and immunohistichemical assessments of cyclosporine a on sciatic nerve regeneration using allografts: a rat sciatic nerve model. Bulletin of Emergency and Trauma, 2017;5(3);152-59. PMID:28795058.

5. Asano F. A novel gait generation method independent of target settling-time adjustment for underactuated limit cycle walking. Multibody System Dynamics, 2015;37(2):227-44. https://doi.org/10.1007/s11044-015-9479-2

6. Bain JR, Mackinnon SE, Hunter DA. Functional evaluation of complete sciatic peroneal and posterior tibial nerve lesions in the rat. Plastic and Reconstructive Surgery, 1987:129-36. https://doi.org/10.1097/00006534198901000-00024 PMid:2909054 
7. Cattin AL, Lloyd AC. The multicellular complexity of peripheral nerve regeneration. Current Opinion in Neurobiology, 2016;39:38-46. https://doi.org/10.1016/j.conb.2016.04.005 PMid:27128880

8. Chen TY, Yang YC, Sha YN, Chou JR, Liu BS. Far-infrared therapy promotes nerve repair following end-to-end neurorrhapy in rat models of sciatic nerve injury. Hindawi Publishing Corporation, 2015;1-10. https://doi.org/10.1155/2015/207245 PMid:25722734 PMCid:PMC4333284

9. Chhabra A, Ahlawat S, Belzberg A, Andreseik G. Peripheral nerve injury grading simplified on MR neurography: As referenced to Seddon and Sunderland classifications. Indian Journal of Radiology and Imaging, 2014;24(3):217-24. https://doi.org/10.4103/0971-3026.137025 PMid:25114384 PMCid:PMC4126136

10. Drake RL, Vogl AW, Mitchell AWM. Gray's anatomy for students flash cards. 3rd ed. Churchill Livingstone Elsevier Inc, Philadelphia. 2015:391.

11. Fletcher A. Action potential: generation and propagation. Anasesthesia and Intensive Care Medicine, 2008;9(6):251-55. https://doi.org/https://doi.org/10.1016/j.mpaic.2019.01.014

12. Fu SY, Gordon T. The cellular and molecular basis of peripheral nerve regeneration. Molecular Neurobiology, 1997;14:67-116. https://doi.org/10.1007/BF02740621 PMid:9170101

13. Gao $X$, Wang $Y$, Chen J, Peng J. The role of peripheral nerve ECM components in the tissue engineering nerve construction. Rev. Neurosci, 2013;24(4):443-53. https://doi.org/10.1515/revneuro-2013-0022

14. Gasparini ALP, Barbieri $\mathrm{CH}$, Mazzer N. Correlation between different methods of gait functional evaluation in rats with ischiatic nerve crushing injuries. ACTA ORTHOP BRAS, 2007;15(5):285-89. https://doi.org/10.1590/S141378522007000500011

15. George ML, Tutton MG, Janssen F, Arnaout A, Abulafi AM, Eccles SA. VEGF-A, VEGF-C and VEGF-D in colorectal cancer progression. Neoplasia, 2001;3(5):420-7. https://doi.org/10.1038/sj.neo.7900186 PMID:11687953 PMCid:PMC1506210

16. Goss JR, Goins WF, Lacomis D, Mata M, Glorioso JC, Fink DJ. Herpes simplex-mediated gene transfer of nerve growth factor protects against peripheral neuropathy in streptozotocin-induced diabetes in the mouse. Diabetes, 2002;51:2227-32. https://doi.org/10.2337/diabetes.51.7.2227 PMid:12086954

17. Greg L. Developmental neurobiology. Academic Press, London. 2009:752.

18. Gustafson KJ, Grinberg Y, Joseph S, Triolo RJ. Human distal sciatic nerve fascicular anatomy: implication for ankle control using nerve-cuff electrodes. JRRD, 2012;49(2):309-22. https://doi.org/10.1682/JRRD.2010.10.0201 PMID:22773531

19. Hargus NJ, Patel MK. Voltage-gated Na+ channels in neuropathic pain. Expert opinion, 2007;16(5): 635-46. https://doi.org/10.1517/13543784.16.5.635 PMid:17461737

20. Hellweg R, Hartung H. Rapid Communication: Endogenous levels of nerve growth factor (NGF) are altered in experimental diabetes mellitus: a possible role for NGF in the pathogenesis of diabetic neuropathy. Journal of Neuroscience Research, 1990;26:258-67. https://doi.org/10.1002/jnr.490260217 PMid:2142224

21. Hobson MI, Green CJ, Terenghi G. VEGF enhances intraneural angiogenesis and improves nerve regeneration after axotomy. J. Anat, 2000;197(4):591-605. https://doi.org/10.1046/j.1469-7580.2000.19740591.x PMid:11197533 PMCid:PMC1468175

22. Huebner EA, Strittmatter SM. Axon regeneration in the peripheral and central nervous systems. Results Probl Cell Differ., 2009;48:339-51. https://doi.org/10.1007/400_2009_19 PMid:19582408 PMCid:PMC2846285

23. Inda AM, García MN, Andrini LB, Garcia AL, Blanco AF, Furnus CC, et al. Evaluation of Angiogenesis with the Expression of VEGF-C and CD34 in Human Colon Cancer. Current Chemical Biology, 2009;3:302-5. https://doi.org/10.2174/2212796810903030302

24. Jiang $L$, Jones $S$, Jia $X$. Stem cell transplantation for peripheral nerve regeneration: current options and opportunities. International Journal of Molecular Science, 2017;18(94):1-17. https://doi.org/10.3390/ijms18010094 PMid:28067783 PMCid:PMC5297728

25. Johnson EO, Zoubos $A B$, Soucacos PN. Regeneration and repair of peripheral nerves. Injury Int J Care Injured., 2005;36(4):24-9. https://doi.org/10.1016/j.injury.2005.10.012 PMid:16288757

26. Kern $\mathrm{S}$, Eichler $\mathrm{H}$, Stoeve J, Kluter H, Bieback K. Comparative analysis of mesenchymal stem cells from bone marrow, umbilical cord blood, or adipose tissue. Stem Cells, 2006;(24):1294-301. https://doi.org/10.1634/stemcells.2005-0342 PMid:16410387

27. Kolch W. Meaningful relationships: the regulation of the Ras/Raf/MEK/ERK pathway by protein interactions. Biochem J, 2000;351:289-305. https://doi.org/10.1042/bj3510289 PMID:11023813 PMCid:PMC1221363 
28. Kuroda $Y$, Kitada M, Wakao S, Dezawa M. Mesenchymal stem cells and umbilical cord as sources for schwann cell differentiation: their potential in peripheral nerve repair. The Open Tissue Engineering and Regenerative Medicine Journal, 2011;4:54-63. https://doi.org/10.2174/1875043501104010054

29. Lundborg G. A 25-year perspective of peripheral nerve surgery: evolving neuroscientific concepts and clinical significance. The Journal of Hand Surgery, 2000:391-414. https://doi.org/10.1053/jhsu.2000.4165 PMid:10811744

30. Lutz $M$, Rosenberg $M$, Kiessling F, Eckstein V, Heger $T$, Krebs J, et al. Local injection of stem cell factor (SCF) improves myocardial homing of systemically delivered c-kit + bone marrow-derived stem cells. Cardiovascular Research, 2008;77:143-50. https://doi.org/10.1093/cvr/cvm027 PMid:18006465

31. Margiana R, Jusuf AA, Aman RA, Liem IK, Pawitan JA. A new method in walking analysis using the angles around the midpoint between print length and toe spread by four different color footprints. IJSBAR, 2015;21(1):117-28. Available at: https://pdfs.semanticscholar.org/c3fa/22e1984373c7174986398eab305c8198b0e6.pdf

32. Marieb EN, Hoehn K. Human anatomy \& Physiology. 9th Ed. Pearson Education, Inc. United Stated. 2013:1107.

33. Martins RS, Bastos D, Siqueira MG, Heise COC, Teixeira MJ. Traumatic injuries of peripheral nerves: a review with emphasis on surgical indication. Arq Neuropsiquiatr, 2013;71(10):811-4. https://doi.org/10.1590/0004282X20130127 PMid:24212521

34. Matsuse D, Kitada M, Kohama M, Nishikawa K, Makinoshima H, Wakao S, et al. Human umbilical cord-derived mesenchymal stromal cells differentiate into functional schwann cells that sustain peripheral nerve regeneration. J Neuropathol Exp Neurol, 2010;69(9):973-85. https://doi.org/10.1097/NEN.0b013e3181 eff6dc PMid:20720501

35. Medinaceli LD, Freed WJ, Wyatt RJ. An index of the functional condition of rat sciatic nerve based on measurements made from walking tracks. Experimental Neurology, 1982;77:634-43. https://doi.org/10.1016/0014-4886(82)90234-5

36. Menorca RMG, Fussell TS, Elfar JC. Nerve physiology mechanism of injury and recovery. Hand Clin, 2013;29:31730. https://doi.org/10.1016/j.hcl.2013.04.002 PMid:23895713 PMCid:PMC4408553

37. Mohammadi R, Ahsan S, Masoumi M, Amini K. Vascular endhothelial growth factor promotes peripheral nerve generation after sciatic nerve transection in rat. Chinese Journal of Traumatology, 2013;16(6):323-29. PMID: 24295576.

38. Monte-Raso VV, Barbieri $\mathrm{CH}$, Mazzer N, Yamasita AC, Barbieri G. Is the sciatic functional index always reable and reproducible?. Journal of Neuroscience methods, 2008;170:255-61. https://doi.org/10.1016/j.jneumeth.2008.01. 022 PMid: 18325595

39. Navarro X, Udina E. Methods and protocols in peripheral nerve regeneratiexperimental research: part iii electrophysiological evaluation. International Review of Neurobiology, 2009;87:105-26. https://doi.org/10.1016/S0074-7742(09)87006-2

40. Pawitan JA, Liem IK, Budiyanti E, Fasha I, Feroniasanti L, Jamaan T, et al. Umbilical cord derived stem cell culture: multiple-harvest explant method. International Journal of PharmTech Research, 2014;6(4):1202-1208. Available at: https://www.researchgate.net/publication/267026055_Umbilical_cord_derived_stem_cell_culture_Multipleharvest_explant_method

41. Pawitan JA, Wulandari $D$, Suryani $D$, Damayanti L, Liem IK. Comparison of flowcytometric immunocytochemistry analysis of stem cell surface markers. Journal of Biological Science, 2015;15(1):1-5. https://doi.org/10.3844/ojbsci.2015.1.5

42. Pawitan JA, Leviana M, Sukmawati D, Liem IK, Margiana R, Tarcisia T. Prospect of umbilical cord mesenchymal stem cell culture wastein regenerative medicine. Journal of Global Pharma Technology, 2017: 1-5. Available at: https://scholar.ui.ac.id/en/publications/prospect-of-umbilical-cord-mesenchymal-stem-cell-culture-waste-in

43. Pereira WC, Khushnooma I, Madkaikar M, Ghosh K. Reproducible methodology for the isolation of mesenchymal stem cells from human umbilical cord and its potential for cardiomyocyte generation. Journal of Tissue Engineering and Regenerative Medicine, 2008;2:394-9. https://doi.org/10.1002/term.107 PMid:18615777

44. Pfister LA, Papaloizos M, Merkle HP, Gander B. Nerve conduits and growth factor delivery in peripheral nerve repair. Journal of the Peripheral Nervous System, 2007;12:65-82. https://doi.org/10.1111/j.15298027.2007.00125.x PMid:17565531

45. Pola R, Aprahamian TR, Bosch-Marce M, Curry C, Gaetani E, Flex A, et al. Age-dependent VEGF expression and intraneural neovascularization during regeneration of peripheral nerves. Neurobiology of Aging, 2004;25:136168. https://doi.org/10.1016/j.neurobiolaging.2004.02.028 PMid:15465634 
46. Pons J, et al. VEGF improves survival of mesenchymal stem cells in infarcted hearts. Biochemical and Biophysical Research Communications, 2007;376(2):419-22. https://doi.org/10.1016/j.bbrc.2008.09.003 PMid:18789891

47. Rosberg HE, Carlsson KS, Cederlund RI, Ramel E, Dahlin LB. Costs and outcome for serious hand and arm injuries during the first year after trauma - a prospective study. BMC Public Health, 2013;(13):501:1-7. https://doi.org/10.1186/1471-2458-13-501 PMid:23706070 PMCid:PMC3681586

48. Rubin DI, Hermann RC. Chapter 105: Peripheral nerve injury. Neurology and Clinical Neuroscience, Philadelphia. 2007:1410-22. https://doi.org/10.1016/B978-0-323-03354-1.50109-7

49. Schulz A, Walther C, Morrison H, Bauer R. In vivo electrophysiological measurements on mouse sciatic nerves. Journal of Visualized Experiments, 2014;86(51181):1-8. https://doi.org/10.3791/51181 PMCid:PMC4166965

50. Seddon HJ. A classification of nerve injuries. British Medical Journal, 1942:237-39. https://doi.org/10.1136/bmj.2.4260.237 PMid:20784403 PMCid:PMC2164137

51. Siemionow M, Bozkurt M, Zor F. Regeneration and repair of peripheral nerves with different biomaterials: review. Microsurgery, 2010;30(7): 575-88. https://doi.org/10.1002/micr.20799 PMid:20878689

52. Silva DN, Coelho J, Frazilio FO, Odashiro AN, Carvalho PTC, Pontes ERJC, Vargas AF, Rosseto M, Silva ABA. Endto-side nerve repair using fibrin glue in rats. Experimental Neurology, 2010;25(2):158-62. https://doi.org/10.1590/S0102-86502010000200007 PMid:20305882

53. Svennigsen AF, Dahlin LB. Review: Repair of the peripheral nerve-remyelination that works. Brain Sciences, 2013;3:1182-97. https://doi.org/10.3390/brainsci3031182 PMid:24961524 PMCid:PMC4061866

54. Tikoo R, Zanazzi G, Shiffman D, Salzer J, Chao MV. Cell cycle control of schwann cell proliferation: Role of cyclindependent kinase-2. The Journal of Neuroscience, 2000;20(12):4627-34. https://doi.org/10.1523/JNEUROSCI.2012-04627.2000 PMid:10844032 PMCid:PMC6772447

55. Tortora GJ, Derrickson B. Principles of anatomy \& physiology. 14th ed. John Wiley \& Sons, Inc. Hoboken. 2014: 1089.

56. Varejao ASP, Cabrita AM, Patricio JA, Bulas-Cruz J, Gabriel RC, Melo-Pinto P, et al. Functional assessment of peripheral nerve recovery in the rat: Gait Kinematics. Microsurgery, 2001;21:383-88. https://doi.org/10.1002/micr.21803 PMID:11757066

57. Varejao ASP, Cabrita AM, Geuna S, Melo-Pinto P, Filipe VM, Gramsbergen A, et al. Toe out angle: a functional index for the evaluation of sciatic nerve recovery in the rat model. Experimental Neurology, 2003;183:695-99. https://doi.org/10.1016/S0014-4886(03)00208-5

58. Volarevic V, Arsenijevic N, Lukic ML, Stojkovic M. Concise review: Mesenchymal stem cell treatment of the complications of diabetes mellitus. Stem Cells, 2011;29(1):5-10. https://doi.org/10.1002/stem.556 PMid:21280154 PMCid:PMC3059410

59. Zarbakhsh S, Goudarzi N, Shirmohammadi M, Safari M. Histological study of bone marrow and umbilical cord stromal cell transplantation in regenerating rat peripheral nerve. Cell J, 2016;17(4):668-77. https://doi.org/10.22074/cellj.2016.3839

60. Zacharek A, Chen J, Li A, Cui X, Li Y, Roberts C, Feng Y, Gao Q, Chopp M. Angiopoietin1/TIE2 and VEGF/FLK1 Induced by MSC Treatment Amplifies Angiogenesis and Vascular Stabilization after Stroke, 2007;27(10):1684-91. https://doi.org/10.1038/sj.jcbfm.9600475 PMid:17356562 PMCid:PMC2796470

61. Zhang $P$, Xue F, Zhao F, Lu H, Zhang H, Jiang B. The immunohistological observation of proliferation rule of schwann cell after sciatic nerve injury in rats. Artificial Cells, Blood Substitutes, and Biotechnology, 2008;36:15055. https://doi.org/10.1080/10731190801932132 PMid:18437591

62. Zuo J, Neubauer D, Graham J, Krekoski CA, Ferguson TA, Muir D. Regeneration of axons after nerve transection repair is enhanced by degradation of chondroitin sulfate proteoglycan. Exp Neurol, 2002;176:221-28. https://doi.org/10.1006/exnr.2002.7922 PMid:12093099

$\diamond \diamond \diamond \diamond \diamond \diamond \diamond$

http://www.ejgm.co.uk 